\title{
Adhesion Lines Pattern as an Indicator of Age in Voles
}

\author{
Galina A. KLEVEZAL \& Anna FEDYK
}

Klevezal G. A. \& Fedyk A., 1978: Adhesion lines pattern as an indicato: of age in voles. Acta theriol., 23, 27: 413-422 [With 1 Table \& 5 Figs].

Examination was made of the bone structure of the mandible and the toe phalanges in three species of voles of known absolute age. In the case of individuals of Microtus agrestis living in summer it is possible to distinguish overwintered individuals from animals born in the given calendar year by the presence in the toe phalanges of adhesion lines of annual growth. On the basis of the structure of the mandible it is also possible to distinguish individuals born during the current year and, additionally, it also possible to establish to which seasonal generation voles in the second calendar year of their life belong. No annual growth adhesion lines were found in the toe phalanges of Clethrionomys glareolus and Pitymys subterraneus. The bone structure of the mandible in $P$. subterraneus made it possible to distinguish between overwintered adults and young individuals which had not lived through a winter. No adhesion lines were found in the mandible of C. glareo:us.

[Inst. Develop. Biology Acad. Sci. USSR, 117334 Moscow and Mammals Res. Inst., Polish Acad. Sci., 17-230 Białowieża].

\section{INTRODUCTION}

It has been shown that voles which have overwintered can be distinguished from those which have not by the presence of adhesion lines in their mandibles (Kleve zal \& Kle i n e $\mathrm{n} \mathrm{berg,1967).} \mathrm{This} \mathrm{method}$ has not, to the best of our knowledge, as yet been used in population studies. There are many methods of estimating age in voles, but none of them is completely satisfactory (see review by P u c e k \& L o w e, 1975). For certain specific purposes, such as distinguishing overwintered animals in the composition of adult individuals in a summer population, there is no such method at all. Adult animals can be segregated into overwintered individuals and those born in the given calendar year only by analysis of bone structure.

The present article forms an attempt at detailed consideration of a method for estimating the absolute age of voles on the basis of bone structure, using animals of known absolute age. Particular attention has been paid in this connection to elaborating a method for defining the age of live animals on the basis of the absence or presence of annual 
growth adhesion lines in digital phalanges analogical with the method elaborated for the genus Apodemus (K le v e z a l, 1973).

\section{MATERIAL AND METHODS}

A total of 70 individuals of Microtus agrestis (L inna e us, 1761), 40 of Pitymys subterraneus (de Sélys-Longchamps, 1835) and 24 of Clethrionomys glareolus (S chreber, 1780) reared in captivity in the Mammals Research Institute, Polish Academy of Sciences, Białowieża were used for analysis of age changes in bone structure. These animals were kept in cages on a conventional diet, at a constant temperature and with natural light rhythm.

In addition a fairly large group of Clethrionomys glareolus caught under natural conditions was also examined and the animals' age estimated on the basis of measurements of tooth root length, using the method proposed by $\mathrm{Pucek}$ \& $\mathrm{Zejda}$ (1968). Detailed studies were made of Microtus agrestis. The age composition of these voles depending, on the time of their birth and the time they were killed is given in Table 1.

Table 1

Number of $M$. agrestis according to the period of birth and death.

\begin{tabular}{|c|c|c|c|c|c|c|}
\hline \multirow[b]{2}{*}{ Months of birth } & \multicolumn{4}{|c|}{ Month of death } & \\
\hline & $\begin{array}{l}\text { Non } \\
\text { May }\end{array}$ & overw & tered & March-May & $\begin{array}{l}\text { Overwint } \\
\text { June-Aug. }\end{array}$ & $\begin{array}{l}\text { red } \\
\text { Sent_Oct }\end{array}$ \\
\hline March-May & 4 & 5 & 1 & 14 & 1 & 1 \\
\hline June-Aug. & & & & 14 & & 13 \\
\hline Sept.-Nov. & & & & 13 & 2 & 2 \\
\hline
\end{tabular}

In the majority of these individuals examination was made of half the mandible and the first and second phalanges of the third or fourth toe, and in a few individuals either the mandible of the phalanges.

The mandibles were cleaned of soft tissues and the toe phalanges were decalcified, together with their surrounding tissues, in $4-5 \%$ nitric acid for $8-12$ hours. After decalcification they were rinsed for 12 hours under running water and sectioned on a freezing microtome. Sections of the mandible, $20-30 \mu$ thick, were rinsed in distilled water, stained with Erlich's hematoxyline and again rinsed in distilled water, then in tap water. After passing the stained sections successively through three water solutions of glycerol of increasing concentration, they were embedded in pure glycerol.

Preparations of the phalanges were obtained as follows: sections $10-12 \mu$ thick were placed on slides in distilled water, then the water drawn off by means of filter paper. Next hematoxyline and then water was transferred on to the sections by means of a pipette, after which the sections were rinsed after staining 2 or 3 times. The rinsed sections were immersed in diluted glycerol $(50 \%)$ an the best of them selected under an eyeglass or binocular and embedded in pure glycerol.

After comparing different parts of the mandible and digital phalanges it was found that the cross-sections through the middle of the mandible and its posterior part, and cross-sections through the corpus and corpus-distal part of the first or second phalanges, were most suitable for analysis of bone structure (Fig. 1). During analysis attention was paid chiefly to the structure of the lower 
lamina of the mandible and ramus mandibulae (see Fig. 2). The structure of the mandible in the perialveolar region and region near the tooth roots is too complicated and unsuitable for analysis of structure depending on age.

\section{RESULTS}

1. Microtus agrestis

In individuals which had not overwintered the bone tissue of the mandible is solid, with a small number of blood vessel canals and is devoid of any adhesion lines (Fig. 3a). In one of the five individuals born in spring and killed in autumn one adhesion line could be seen near the margin in corpus mandibulae. The medullary cavity can be seen in sections of digital phalanges, with a central zone surrounding it, and bounded from the exterior by a wavy line (resorption line - r.1.), and on the exterior a ring of periosteal bone tissue, in which there is no adhesion line (Fig. 4a).

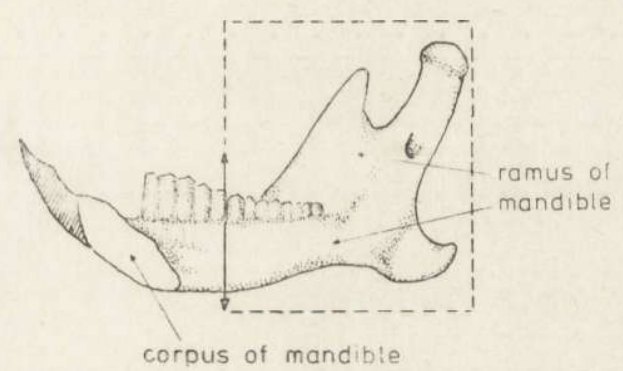

Fig. 1. Diagram of the mandible in $M$. agrestis.

Plane in which preparations were sectioned is indicated by an arrow. The part of the mandible most suitable for analysis of bone structure depending on age is indicated by a dotted line within the frame.

In all individuals which had overwintered - irrespective of the season of birth and time of death - one, or more rarely two, adhesion lines can be seen in the periosteal zone in sections of digital phalanges (Fig. 4b, c), situated near the resorption line, or sometimes near the external wall of the bone. In the material analysed no direct connections were found between the number of adhesion lines, or the distribution of these lines, and the season of the animals' birth and death.

From zero to six adhesion lines were observed in sections of the mandible in overwintered voles. The number of these lines differs in animals originating from different generations and killed at different seasons. Among animals killed in spring, those individuals born in autumn (September-October) differ distinctly in respect of the number and arrangement of adhesion lines from those born in spring or summer (March- 
August) of the previous year. In the majority of voles of the autumn generation the mandibular bone structure is solid, without a continuous adhesion line. There may be one, or less often two, indistinct lines, visible only in separate parts, most often in ramus mandibulae (Fig. 3b). in four out of twelve individuals, however, there is one adhesion line
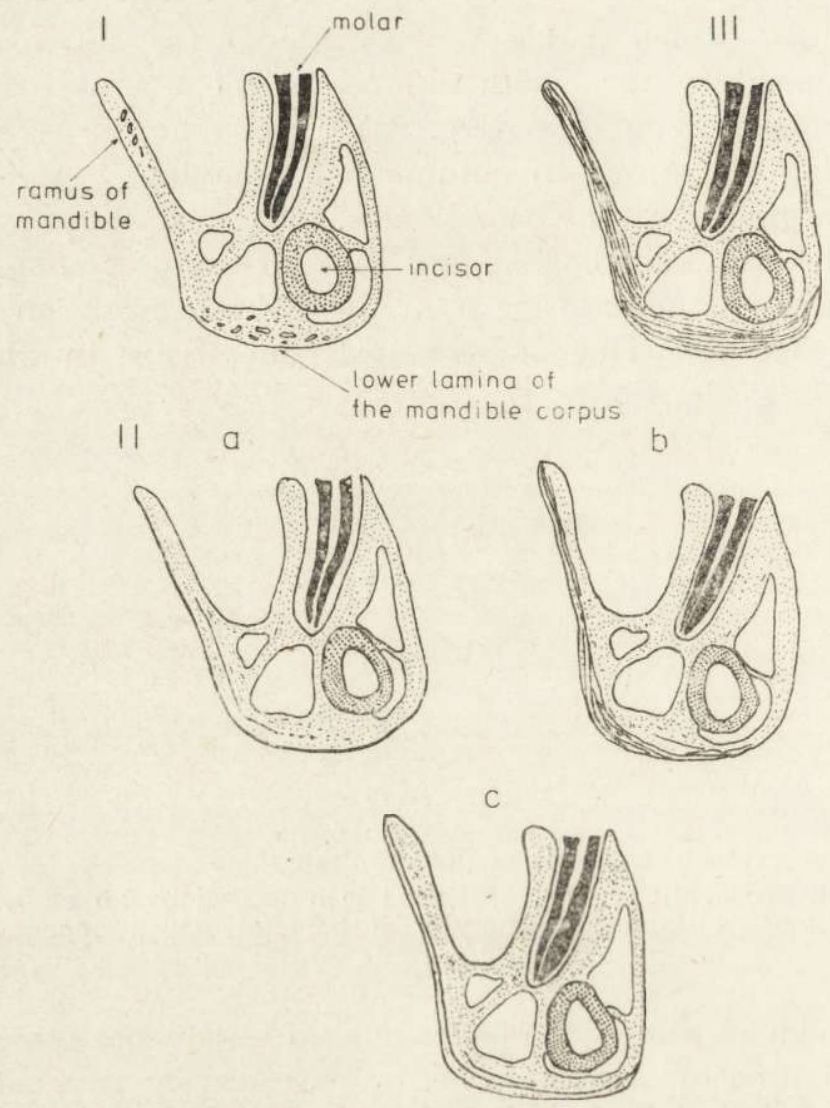

Fig. 2. Diagrams of cross-section through mandible of $M$. agrestis.

i - in non-overwintering animals, born in spring and killed in spring, summer or autumn: II - in overwintered animals killed in spring: (a) typical cross-section of the mandible in individuals of the autumn generation, (b) typical cross-section of the mandible in spring-summer generations, (c) cross-section of the mandible encountered in a small number of animals of both the above-mentioned seasonal generations: III - in overwintered animals killed in autumn.

not composed of several finer lines and situated in the lower solid lamina of corpus mandibulae and ramus mandibulae. Occasionally 1-2 supplementary lines can be seen near it, which are less distinct and not visible in all parts of the section (Fig. 3c). 
In the majority of voles of the spring and summer generations, during the second calendar year of their life from two to six uniformly distinct adhesion lines are observed in the mandible, which lines, in separate parts of the section, most often in ramus mandibulae, may fuse and form more distinct adhesion lines, or occasionally one strongly defined line (Fig. 3d). Only in one out of twelve individuals belonging to this generation was one adhesion line observed in the mandible, that is, a picture similar to that observed in four voles born in autumn.

No differences were observed in the number and course taken by adhesion lines in mandibles of individuals of the spring and summer generations, in which from three to six uniformly distinct adhesion lines were observed.

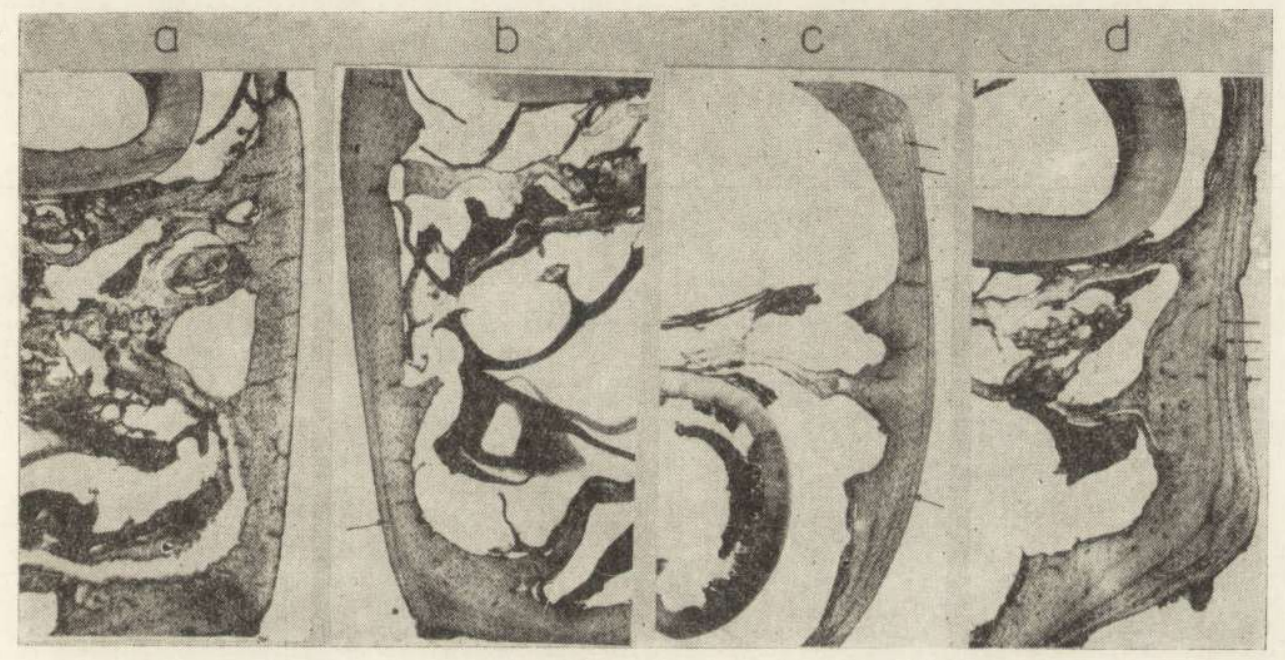

Fig. 3. Cross-sections of the lower solid lamina of the mandible in M. agrestis photographs of stained preparations.

a - non-overwintering animals, b, c - overwintering animals of the autumn seneration killed in spring, d - overwintered animals of the spring generation, killed in spring. Adhesion lines indicated by arrows.

Thus, if the number, distribution and distinctness of adhesion lines in the mandible are taken into consideration, it is possible to distinguish between overwintered animals and individuals which had not overwintered and, in some cases, it is possible also to distinguish representatives of different seasonal generations among voles in the second calendar year of life. A diagram is given in Fig. 2 representing the main types of mandibular structure from the aspect of the feature analyzed. Among voles killed in autumn it is possible to distinguish the current year's 
individuals from those which had overwintered. The first of these have not any adhesion line (Fig. 2-I) or have one non-continuous line visible only in parts of the section. The remainder have from three to six adhesion lines (Fig. 2-III), but always a minimum of three. Among indi-

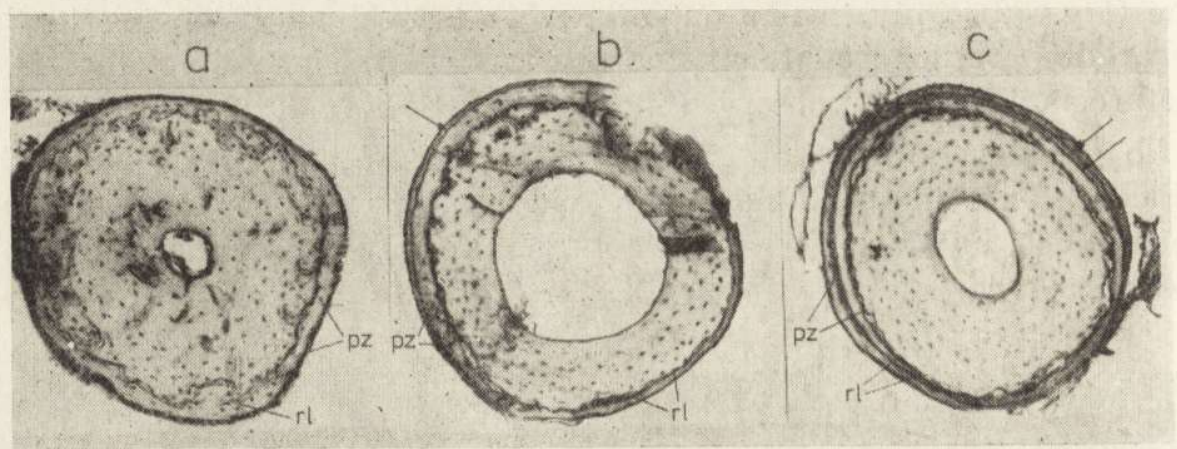

Fig. 4. Cross-sections of the corpus of digital phalanges in M. agrestis.

Photographs of stained preparations. a - non-wintering, b, c - overwintered. Arrows show adhesion lines, r.l. - resorption line, p.z. - periosteal zone.
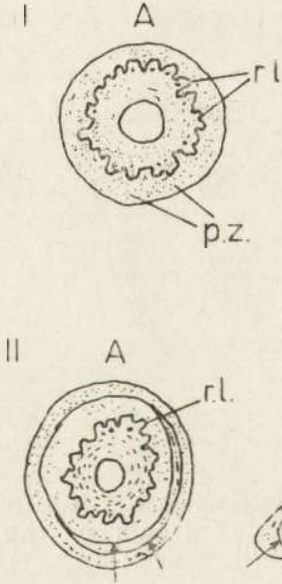

B

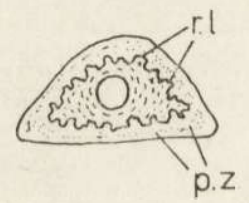

B

Fig. 5. Diagram of cross-sections of digital phalanges in M. agrestis.

A - through corpus of phalanges, B - through distal part of phalanges, I - in non-overwintering animals, II - in overwintered animals. Symbols as in Fig. 4.

viduals killed in autumn there were only two animals of the autumn generation, the remainder belonging to the summer generation. This may perhaps be the reason why no differences could be found among them in the formation of the feature analyzed.

Among voles killed in spring it is possible to distinguish the indivi- 
duals which had overwintered, and among these, animals of the autumn and spring-summer generations. In the material at our disposal animals of the autumn generation $(n=12)$ and spring-summer generation $(n=22)$ differed distinctly in respect of two features: (a) there is not a single distinct continuous adhesion line running through the whole of the section analyzed, but there is sometimes one line visible in small parts of the cross-section and then there are no supplementary lines surrounding it (Fig. 2IIa), and (b) there are from 2 to 6 lines, uniformly distinct, fusing in places with a smaller number of very distinct lines (Fig. 2-IIb). The number of adhesion lines significantly differs in these two generations. Some of the individuals belonging to the above two generations, however, have a different "common " type of structure. In their mandibles there is one distinct line, surrounded in places by supplementary lines visible only in small parts of the section (Fig. 2-IIc).

If individuals born in the given calendar year are small in spring, they can be easily distinguished on the basis of both body weight and structure of the bone tissue of the mandible, which is not solid but "lacy". During this time they cannot be mistaken for overwintered animals of the autumn generation which, although also not possessing adhesion lines, have solid bone structure. If there is any doubt about dividing the spring population into two groups, examination should be made of sections of the digital phalanges, since all individuals of the autumn generation in spring have one adhesion line, unlike the current year's individuals.

\section{Pitymys subterraneus and Clethrionomys glareolus}

No adhesion lines were found in sections of the digital phalanges in either species, even though series of preparations were examined.

There were either no adhesion lines, or one distinct line without supplementary lines, in mandibles of European pine voles which had not overwintered. In the overwintered individuals of this species examined in summer and autumn, from one line (surrounded by supplementary lines not occurring throught the whole length of the section) to three lines could be observed in the lower solid lamina of corpus mandibulae and in ramus mandibulae. It is therefore possible to distinguish overwintered individuals from those which had not overwintered by the number of adhesion lines and the presence or lack of supplementary lines. The maximum number of adhesion lines in $P$. subterraneus is, however, smaller than in $M$. agrestis. The small amount of material at our disposal made it impossible to carry out analysis of seasonal - age differences. Bone structure in the mandible of C. glareolus is different from that in 
M. agrestis. No morphological features of a seasonal or age character, permitting of at least distinguishing overwintered animals among adult individuals, were observed in this species.

\section{DISCUSSION}

The studies carried out showed that the number of adhesion lines in the mandible of $M$. ugrestis is only occasionally equal to the number of winters through which the animal has lived and thus fail to confirm earlier data given for this species (Klevezal \& Kleine nberg, 1967). The method of defining age from the presence, number and course taken by adhesion lines in the mandible does not, however, become less useful. Under natural conditions voles do not survive two winters and therefore the existence in overwintered individuals of several adhesion lines is not an obstacle to using bone structure for estimating absolute age. It is an important fact that bone structure of the mandible is significantly different in overwintered animals from that in individuals which have not overwintered.

The number of adhesion lines in the periosteal zone of digital phalanges corresponds more closely to the number of winters survived. In individuals which had not overwintered there is not a single line, but in overwintered individuals there is most often one, less often two, lines. Therefore in order to segregate adult individuals of $M$. agrestis into overwintered animals and current year's individuals it is better to make use of digital phalanges. An additional advantage is the fact that this is a method which can be used with live animals, obtaining the toes during marking by toe-clipping.

The periosteal zone of digital phalanges presumably grows for a shorter time than that of the mandible and consequently fewer adhesion lines are formed in it. Absence of adhesion lines in the periosteal zone of phalanges in overwintered individuals of $P$. subterraneus and C. glareolus can be explained by the fact that in such animals with small body dimensions the phalanges complete growth in thickness earlier, even before winter. In this case it is to be expected that the method for estimating age in live animals is suitable not only for $M$. agrestis but also for other large voles such as $M$. oeconomus.

By taking into consideration the number of adhesion lines in the mandible of voles killed in spring, it was possible to distinguish between individuals of the autumn and spring-summer generations in the sample examined. Some of the individuals - in this particular case $15 \%$ - were however impossible to distinguish. It may be that in a large amount of material relating to individuals of known absolute age, it would be pos- 
sible to discover more features differentiating these »undecided « individuals. During separation of voles into the two above-mentoned generations it is possible to adopt a different method. If in a sample from a natural population in spring the three types, presented in the diagram (Fig. 2-II), of distribution of adhesion lines in the mandible can be observed among overwintered animals (and if the number of "undecided" individuals in the sample does not differ significantly from the number given in the present study), then it can be taken as certain that no important error will be made if we separate individuals of the autumn and spring-summer generations according to the presence of 2 to 6 adhesion lines or their absence (Fig. 2-IIa and 2-IIb), and in the case of individuals with this feature common to these generations (Fig. 2IIc) we allocate them conditionally to the given generation, on the basis of confidence intervals calculated according to the data presented here.

The problem of the degree to which the picture of bone structure depending on age, described here, corresponds to that existing in natural populations remains open, since the individuals analyzed in this study were laboratory-bred animals. A knowledge of factors defining the character of adhesion lines, and consequently of yearly increase in growth in mammals (Klevezal \& Mina, 1973) permits of assuming that in natural populations variations in number and distribution of adhesion lines will not be greater than in the sample of captive animals studied here. This in turn gives grounds for concluding that the method proposed for estimating age and appurtenance of seasonal generations is suitable for natural populations.

\section{REFERENCES}

1. Klevezal G. A., 1973: Ob ograničenijah i novyh vozmožnostjah ispolzovanija sloev v tkanjah zuba i kosti dlja opredelenija vozrasta mlekopitajuščih. Zool. žurn., 52, 5: 757-765.

2. Klevezal G. A. \& Kleinenberg S.E., 1967: Age determination of mammals by layered structure in teeth and bone. Izd. „Nauka”: 1-144. Moskva [In Russian, or English translation - Age determination of mammals from annual layers in teeth and bones, Israel Program for Scientific Translations, Jerusalęm, $128 \mathrm{pp}, 1969]$.

3. Klevezal G. A. \& Mina M. V., 1973: Faktory opredelajuščie harakter godovyh sloev v zubah i kosti mlekopitajuščih. Žurn. obšč. biol., 34, 4: 594-605.

4. Pucek Z. \& Lowe P. W., 1975: Age criteria in small mammals. [In: F. B. Golley, K. Petrusewicz \& L. Ryszkowski (Eds): Small mammals: their productivity and population dynamics]. Cambridge Univ. Press: 55-72. Cambridge.

5. Pucek Z. \& Zejda J., 1968: Technique for determination age in the red-backed vole, Clethrionomys glareolus (S chreber, 1780). Small Mammals Newslett., 2: $51-60$.

Accepted, February 28, 1978. 
Galina A. KLEVEZAL i Anna FEDYK

\section{LINIE SKLEJANIA JAKO WSKAŹNIK WIEKU U POLNIKOW}

\section{Streszczenie}

Zbadano strukturę kości żuchwy i falang palców na obecność, ilość i układ linii sklejania, łączących słoje przyrostu rocznego. Badaniem objęto 3 gatunki polników: Microtus agrestis, Pitymys subterraneus i Clethrionomys glareolus o znanym wieku bezwzględnym. Opisano metodykę analizy struktur kostnych (patrz Ryc. 1 i 2).

Szczegółowe badania przeprowadzono na polniku burym, M. agrestis, badając llość i układ linii sklejania w zależności od sezonu urodzenia i śmierci zwierząt.

Latem wśród dorosłych $M$. agrestis można wyróżnić przezimki od zwierząt urodzonych $w$ danym roku kalendarzowym po obecności w palcach słojów przyrostu rocznego (Fot. 4). Na podstawie zaś budowy żuchwy można również wydzielić osobniki tegoroczne, a wśród polników w drugim raku ich życia kalendarzowego określić przynależność do generacji sezonowych (Ryc. 2 i Fot. 3). U pozostalych gatunków nie znaleziono rocznych słojów przyrostu na skrawkach falang palców. Jednakże na podstawie budowy żuchwy u darniówek można wydzielić przezimki od zwierząt, które nie zimowały. W żuchwie nornicy rudej nie zaobserwowano żadnych morfologicznych cech sezonowo-wiekowych, umożliwiających choćby wyróżnienie przezimków. Proponowana metoda szacowania wieku względnego nadaje się więc jedynie dla Microtus agrestis. 